Gönderim Tarihi: 25.10.2018 Kabul Tarihi: 28.12.2018

\title{
EKONOMIKK KRİZLERİN KÜÇÜK VE ORTA BOY İŞLETMELER (KOBİ) ÜZERINNDEKİ ETKİLERİ: VAN ÖRNEĞİ
}

\author{
Abdullah OĞRAK ${ }^{*}$ \\ Sinan KIBAR ${ }^{* *}$ \\ Celal KIZILDERE ${ }^{* * *}$ \\ THE IMPACT OF ECONOMIC CRISISS ON SMALL AND \\ MEDIUUM SIZE ENTERPRISES (SME): VAN SAMPLE
}

$\ddot{O} \mathbf{z}$

Ekonomik krizler ile ekonomide meydana gelen daralmalar sonucu birçok ekonomik alan olumsuz etkilenir. Söz konusu alanlardan bir tanesi de reel sektördür. Reel sektörün içinde yer alan Küçük ve Orta Boy İşletmeler (KOBİ) ise bu etkileşimden paylarına düşeni alırlar. İşte yapılan bu çalışmanın amacı, Dünyada ve Türkiye'de yaşanan ve etkileri şu anda da devam eden 2000 yilı ve sonrasındaki küresel ekonomik krizlerin, KOBİ'ler üzerindeki etkilerini incelemektir. Bu bağlamda, Ülkemizin 2000 yılı ve sonrasında yaşadığ ekonomik krizlerden olan 2000 Şubat ekonomik krizi, 2001 Kasım krizi ve 2008 yılında yaşanan küresel çaptaki finansal krizlerin başlangıcı, sebepleri ve etkileri incelenmiştir. Uygulama kısmında, anket çalışması yapılmış ve elde edilen sonuçlar SPSS istatistiki program kullanılarak analiz edilmiştir. Araştırmaya katılan KOBI'lerin \%82,2 i krizin işletmeleri olumsuz etkilediğini belirtirken; $\% 17,8$ i kısmen olumsuz etkilediğini belirtmişlerdir. Araştırmaya katılan işletmelerden hiçbiri krizin işletmelerini etkilemediğini belirtmemişlerdir. Elde edilen veriler ve KOBİ'lerin ekonomi için önemi düşünüldüğünde KOBİ'lerin, krizlere karşı strateji geliştirme gerekliliği ön plana çıkmaktadır.

Anahtar Kelimeler: Ekonomik Kriz, Kriz Yönetimi, KOBİ.

\begin{abstract}
Due to the economic crisis and the contraction in the economy, many economic areas are affected negatively. One of these areas is the real sector. Small and Medium Enterprises (SMEs) in the real sector take their share from this interaction. The aim of this work done, taking place in the world and Turkey and is currently ongoing effects of the global economic crisis and its aftermath in 2000 , is to examine the impact on SMEs. In this context, we examine the

\footnotetext{
* Dr. Öğr. Üyesi, Van Yüzüncü Yıl Üniversitesi, İiBF, İşletme Bölümü, e-posta: abdullahograk@yyu.edu.tr

${ }^{* *}$ Uzman, KOSGEB, e-posta: sinankibar@gmail.com

**** Dr. Öğr. Üyesi, Van Yüzüncü Y1l Üniversitesi, Erciş İşletme Fakültesi, İktisat Bölümü, e-posta: celalkizildere @yyu.edu.tr
} 
beginning, causes and effects of the 2000 February economic crisis, the November 2001 crisis and the global financial crises of 2008, which were the economic crises of our country in 2000 and after. In the application part, a questionnaire study was conducted and the results were analyzed using SPSS statistical program. When we look at the share of SMEs in our country's economic structure, SMEs constituting $99.9 \%$ of total enterprises account for $78 \%$ of total employment, $55 \%$ of total added value, $65.5 \%$ of total sales, Of total exports and $59 \%$ of total exports. When we look at this framework, the effects on the SMEs operating in the service sector in Van are of great importance in terms of the importance of SMEs and the impact of the crisis.

Keywords: Economic Crisis, Management of Crisis, SME.

\section{Giriş}

Türkiye'de son 30 yıllık sürece bakıldığında ekonomiyi etkileyen birçok finansal krizlerin çıktığını söylemek mümkün olabilir. $\mathrm{Bu}$ süreçte özellikle 15-20 yıllık zaman diliminde, birçok kriz yaşanmıştır. Bunlar 1994 Nisan krizi, 2000 Kasım krizi, 2001 Şubat krizi ve 2008 küresel krizleridir. 2008 küresel kriz, gelişmekte olan birçok ülkeyi etkilediği gibi Türkiye'yi de büyük oranda etkilemiştir. İşletmelerin piyasadaki rekabet durumunu etkileyen 2008 krizinde, başta küçük ve orta ölçekli işletmeler olmak üzere birçok şirket iflas etmiş veya kapanma noktasına gelmiştir.

Teknolojideki ve finansal araçlardaki baş döndürücü yenilikler ise özellikle sermaye ve işgücü akımlarının, daha hızlı bir şekilde küreselleşmesine yol açmıştır. Günümüzde başladığı varsayılan sanayi 4.0 devrimi ile de bu sürecin, artarak devam edeceğini göstermektedir. $\mathrm{Bu}$ nedenle ülkelerin sanayi devrimini yakalamak için katma değeri yüksek olan teknolojik değerli ürünler üretmesi gerekmektedir. Tabi bu durum ekonomik ilişkilerin daha karmaşık olmasını beraberinde getirmektedir. Bunun sonucunda finansal araçlardaki çeşitlilik artmakta ve bu olgu finansal krizleri tetiklemektedir. Zaten günümüzde Amerika Birleşik Devletleri (ABD) ile Çin arasında başladığı varsayılan ticaret savaşları da bunun bir göstergesi olarak düşünülebilir.

KOBI'ler ülke ekonomisi içerisinde istihdam, katma değer ve bölgesel kalkınmada ciddi oranda paya sahiptir. KOBI'ler hemen hemen her ülkede çeşitli şekillerde desteklenmektedirler. KOBI'lerin ölçeklerinin küçük olmasının gerektirdiği bazı avantajları olduğu kadar, dezavantajları da söz konusudur. Ancak küreselleşme ile birlikte sayısı ve çeşidi artan küresel ekonomik krizler de KOBI'lere ciddi ve kalıcı zararlar vermektedir. $\mathrm{Bu}$ zararların en aza indirilebilmesi hem ekonomik hem toplumsal anlamda önem arz etmektedir (Demirci 2005:27 ve Güzel 2010: 22) . Dolayısıyla, bu çalışma KOBİ'lerin krizleri etkin bir şekilde 
yönetmeleri ve krizle ilgili yeni bir bakış açısına sahip olmaları bakımından önemlidir.

Yapılan bu çalışmada ilk önce Kriz, Küresel Ekonomik Kriz ve Kriz Yönetimi ile ilgili temel kavramlar açıklanmaya çalışılmıştır. Daha sonra ise, ülkemizdeki Ekonomik Krizlerin tarihsel sürecini, nedenlerini, yapısını ve özellikle 2000 yılı sonrası yaşanan ekonomik krizler ele alınarak incelenmeye çalışılmıştır. Çalışmanın sonunda da, 2000 yılı sonra yaşanan ekonomik krizlerden etkilenen Van ilinde hizmet sektöründe faaliyet gösteren Küçük ve Orta Büyüklükteki İşletmelerin kriz öncesi, anı ve sonrasında finans, yönetim, pazarlama, üretim vb. konularda krizden nasıl etkilendikleri ve krizi yönetme süreçleri incelenmiştir. $\mathrm{Bu}$ inceleme sırasında Küçük ve Orta Büyüklükteki İşletmeler (KOBİ) ile birebir görüşmeler ve alan araştırması olarak anket çalışması yapılmıştır. Çalışmanın başka iller ve başka zaman dilimleri kullanılarak genişletilebilir olduğu düşünülmektedir.

\section{Teorik Çerçeve}

Ekonomik kriz, çeşitlenen ihtiyaçların karşılanma noktasında kaynakların yetersiz kaldığı andan itibaren başlar. Bu andan itibaren makro ve mikro ekonomik göstergelerin olumsuz etkilenme süreci başlamış olur. Ekonomide durgunluk, tüketicilerin satın alma davranışı, yatırımlar, milli gelir düzeyi, kamu harcamaları, bankacılık sektörü, borsa, dış ticaret ve istihdam ekonomik krizlerin ilk akla gelen etkileridir (Eğilmez 2008). İşletmeleri ve ülkeleri etkilerini en aza indirebilmek için temel kavramlar olan kriz, küresel ekonomik kriz ve kriz yönetimi bu bölümde açıklanmaya çalışılacaktır.

Ekonomik bir sistem olan kapitalizm, özel mülkiyetin olduğu ve serbest pazara dayalı ekonomik bir sistemdir. Dolayısıyla üretim araçlarını ellerinde bulunduranların ödüllendirildiği ve herkesin katkısı ve yeteneği oranında gelirden pay aldığ 1 bu sistem, şimdiye kadar dünyada en iyi sistem olarak kabul edilmektedir (Albert 2004: 12; Perelman 2008: 36). Küreselleşme ise, kapitalizmin en üst seviyede vücut bulmasıdır. Bu nedenle kapitalizmin doğasında var olan kriz oluşturucu mekanizma, küreselleşme aracılığı ile bütün dünyaya yayılır (Delice 2003: 57-81). Başka bir deyişle kriz, önceden tahmin edilebilecek ekonomik bir olgunun, sonradan tahmin edilemez bir şekilde ortaya çıkması durumu olarak ifade edilebilir (Goodhart 2008). Bunun nedeni ise, ekonomiye yön veren Uluslararası Para Fonu (IMF) gibi uluslararası kuruluşların, yüksek büyüme için riskli ekonomik varlıkları desteklemesi argümanını savunmaları olmuştur. 
Son günlerde daha sık duyulmaya başlanılan kriz sözcüğü, çoğunlukla tıp ve psikoloji alanlarında kullanılmakta ve bu alanlarda kriz; hastalı̆ı̆n dönüm noktası, hastanın iyileşeceği veya öleceğinin belli olduğu an olarak tanımlanmıştır (Tuğlacı 1997:184). Politik alanda kriz sözcüğü; bir karar organına ait temel amaçların tehdit edildiği süreç olarak nitelendirilmektedir. İktisat biliminde ise kriz; bir ekonomik örgütün, varlığını eskisi gibi devam ettirememesi ve örgütün normal koşullara ulaşabilmek için gerekli değişiklikleri yapmak zorunda olduğu süreç olarak ifade edilmektedir (Emin 2001: 84).

Ekonomi literatüründe kriz durumu enflasyon, işsizlik, durgunluk ve bütçe açıkları gibi kriterlerle açıklanır. Uluslararası ekonomik sistemin, ilkelerinin uygulanmasındaki genel başarısızlık veya hükümetler tarafından verilen bazı kararlar ekonomik kriz sebebi olarak görülür (Blokck 1979: 22). Kriz, varlığı ile karar verme birimlerini şaşırtan ve kararsızlığa sürükleyen bir kavram olarak ifade edilmektedir (Irvine 1987: 37) Farklı disiplinlere bakıldığında her disiplin açısında kriz kendi literatüründe tanımlanmıştır. Örneğin; sosyal bilimlerde bir çalışma alanı olan ve bunalım/buhran anlamına gelen kriz, Yunancadaki "krisis" kelimesinden gelmektedir (Turgut 2006; Emsen 2003). Kriz işletmelerin mali dengelerini bozacağı için, beklenmeyen durumlara hazırlıksız yakalanmamaları adına gerekli tedbirleri alma ve yönetme sanatı olarak da nitelendirilebilir. Dolayısıyla, yaşanan krizlerin kaçınılmaz olarak işletmelerin özellikle finansal yapısı ve ünü üzerinde olumsuz etki oluşturmaktadır (Mitroff 1987: 283). Wolhberg'e göre kriz, örgütsel bir problemin etki alanın hızlı bir şekilde en yüksek noktaya ulaşmasıdır (Wolhberg ve Christian 1989:8). Bu nedenle kapitalizmin doğasında var olan kriz oluşturucu mekanizma, küreselleşme aracılığı ile bütün dünyaya yayılır (Tabb 2008: 30). Bunun da finansal araçlardaki çeşitlilik ile sermaye hareketliliği ve IMF'nin rolü olmak üzere iki temel nedeni vardır. Çünkü IMF asıl amacını görmezden gelerek, bütün enerjisini sermaye hareketliliğinin önündeki engelleri ortadan kaldırmak için harcamaya başlamıştır (Stiglitz 2002). Ayrıca, zayıf denetim ve piyasa yapısındaki eksiklikler nedeni ile uygulanan yanlış politikalar ve sermayenin reel sektörden çekilip finansa kanalize olması, dünyanın bu süreci yaşamasına yol açmıştır (Hui ve Wei 2008; Yıldırım 2010). Krizin zirve yaptığı nokta ise, Lehman Brothers'in yapmış olduğu iflas başvurusu olmuştur (Mendoza ve Quadrini 2010).

Bütün bu tanımlamalara bakıldığında, krizlerin birtakım özellikler taşıdığı söylenebilir. Bunlar arasında acil müdahale gerektirmesi ve zaman baskısı, beklenmedik ve ani değişimlerle ortaya çıkması (sürpriz olmas1), karar vericilerde gerilime yol açması, korku ve paniğe neden 
olmas1, kontrol edilme güçlüğü ve beraberinde firsat ve tehditleri getirmesi vb. gibi özellikler sıralanabilir (Gürsoy 1989).

\subsection{Ekonomik Kriz Kavramı ve Ekonomik Kriz Türleri}

Ekonomik bir olgu olan ekonomik kriz, kelime anlamı ile bunalım veya buhranla eşanlamlıdır. Kriz sonucunda üretimde düşüşler başlar ve refah seviyesi gittikçe düşer (Emsen 2003: 15). Roubini ve Mihm (2012)'ye göre ise ekonomik krizler salgın hastalıklara çok benzerler. Çünkü başladıktan sonra dişarı doğru yayılırlar (Roubini ve Mihm 2012: 17) Malların, hizmetlerin, üretim faktörlerinin veya döviz piyasalarında bulunan fiyat ve miktarlarda normal genel seviyelerindeki artış veya azalışlara ekonomik krizler olarak adlandırılır (Kibritçioğlu 2001:175). Ekonomik kriz, mal, hizmet ve üretim faktörlerinin ekonomik değişmedeki artış veya azalışa uymayarak büyümelerinin yavaşlaması, durması veya küçülmeye başlayarak yok olma olgusudur. Ayrıca 2007 yılının sonlarına doğru ABD'de başlayan ve 2008 yılında ivme kazanan küresel kriz, gelişmiş ve gelişmekte olan ülkeleri derinden etkilemesi nedeni ile 1929 krizinden sonra görülen en şiddetli kriz olarak tanımlanmasına yol açmışır (Bakır 2018: 7). Genellikle krizlerin etkilerinin biraz daha geç geldiği işgücü piyasalarının, bu etkilerden kurtulmaları uzun zaman almaktadır. Türkiye'nin 2001 krizinden sonra yakaladığı yüksek büyüme rakamlarına rağmen işsizlik oranlarında önemli değişikliğin ortaya çıkmaması buna en iyi örnek gösterilebilir (Öksüzler ve Teyyare 2010: 147).

İşletmelerde satışların düşmesi ile başlayan kriz, pazar paylarında meydana gelen kayıplarla devam etmektedir. Pek çok faktöre dayanan söz konusu krizleri, finansal krizler ve reel sektör krizleri şeklinde bir ayırıma tabi tutmak mümkündür. Reel sektör krizleri, kendi içinde, mal ve hizmet piyasasında kriz, iş gücü piyasasında işsizlik krizi olarak, finansal krizler ise para krizi, bankacılık krizi ve dış borç krizi olarak ayrılabilmektedir (Kınaytürk 2006: 175). Ekonomilerin karşı karşıya kaldığı en yaygın finansal kriz, döviz krizi olarak da adlandırılan para krizleridir (Vergil ve Teyyare 2014: 10).

Reel sektör krizleri, ekonominin reel üretim sektörlerinde meydana gelir ve istihdam ile üretimdeki daralmalardan kaynaklanır. Akabinde enflasyon krizi, işsizlik krizi gibi krizler baş gösterir. Aslında herhangi bir sektörde başlayan kriz, diğerini de doğrudan etkilemektedir (Çağlar 2010: 20).

Krizin hangi türü olursa olsun ekonomilerin bütün sektörlerini etkilemektedir. Dolayısıyla, reel sektör de bu etkilenmeden payına düşeni 
almaktadır. Bunun sonucu olarak büyüme oranları düşmekte, kamu borç seviyeleri artmakta ve bütçe açıkları büyümektedir. Kısaca küresel finansal krizler, sistem içindeki aksaklıkların da ortaya çıkmasına neden olmaktadir (Nanto 2009).

Şekil 1: Ekonomik Kriz Türleri

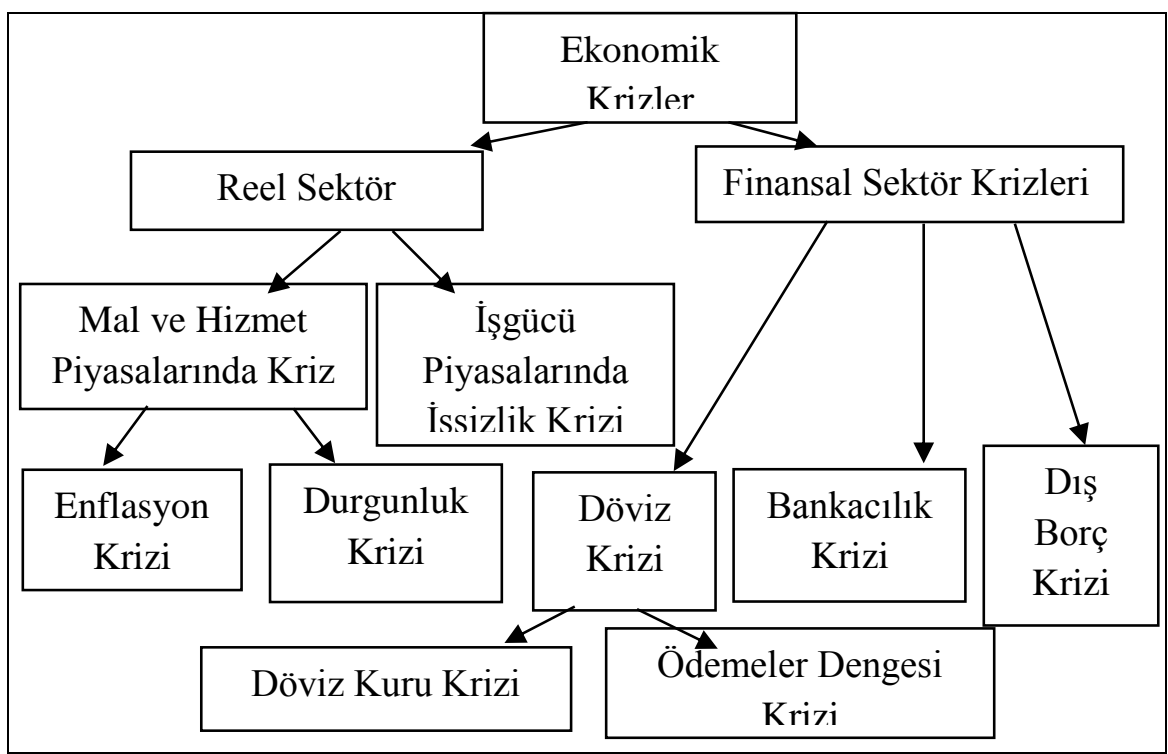

Kaynak: Kibritçioğlu 2001:175

\section{Metodoloji}

Araştırmanın bu bölümünde, ekonomik krizler ve 2000 yılı sonrasında yaşanan ekonomik krizlerin hizmet sektöründe faaliyet gösteren KOBI'lere etkilerinin incelenmesi ve krizin işletmeler üzerindeki etkilerinin ortaya konulması için, Van'da hizmet sektörünün farklı alanlarında faaliyet gösteren işletmelere yönelik bir araştırma yürütülmüş ve sonuçlar ortaya konulmaya çalışılmıştır. Bunun için Van'da hizmet sektöründe faaliyet gösteren işletmeler evren olarak seçilmiştir. Çalışmanın örneklemini ise söz konusu evren içinde yer alan KOBİ'ler oluşturmaktadır. Bu çalışma 2014-2017 yılları arasında işletmelerden elde edilen veriler ve bunların istatistiki analizlerinin yorumlanmasından ortaya çıkmıştır.

Anket formu hazırlanırken özellikle istatistiksel analizlere imkân tanımasına dikkat edilmiştir. Bu nedenle sorularda nominal (sınıflayıcı) ve aralıklı ölçekler kullanılmıştır. Sınıflayıcı ölçek hizmet işletmelerinin yapısı hakkındaki bilgileri toplamak için, aralıklı ölçek ise katılımcıların 
fikirlerinin ne yönde olduğunu belirlemek amacı ile kullanılmıştır. Aralıklı ölçeğe örnek olarak anket çalışmalarında sık kullanılan likert tipi ölçekler gösterilmektedir (Gegez 2007: 195). Literatür taramas1 sonucunda ulaşılan kaynaklardan istatiksel olarak doğruluğu ispatlanmış çalışmalarda kullanılan ölçeklerden çıkarılan sorulardan ve tarafımızdan oluşturulan sorulardan bir ölçek geliştirilmiştir (Durgun 2010; Ekşi 2007; Alıç vd. 2009; Çağlar 2010; Yalçın ve Gafuroğlu 2008)

$\mathrm{Bu}$ araştırma, tarama modelinde betimsel bir araştırmadır. Van'da değişik alanlarda faaliyet gösteren firmaların küresel ölçekte meydana gelen krizlerden nasıl etkilendikleri ve özellikle 2000 yılından sonra meydana gelen krizlerin işletmeler üzerindeki etkilerinin incelenmesi ve belirlenmesi amacıyla tasarlanmıştır. Çalışmaya konu olan olgu ve olayların içinde bulunulan sektörün nicel ve nitel şartları çerçevesinde olduğu gibi tanımlanmaya çalışıldığı bu araştırma, belli bir zaman aralığında, yöneticilerin veya katılımcıların araştırılan konu ile ilgili algılarını tespit etmeye çalışmaktadır.

Araştırmanın uygulama bölümünde, Ekonomik Krizlerin İşletmelere Etkileri ve 2000 Yılından Sonra Yaşanan Ekonomik Krizlerin Hizmet Sektöründe Faaliyet Gösteren işletmelerin İncelenmesi ve krizin işletmeler üzerindeki etkilerini ortaya koymak amaciyla, Van'da farklı alanlarda faaliyette bulunan KOBİ niteliğindeki işletmelerde yürütülen bir araştırma ve sonuçları ortaya konulmaya çalışılmıştır. Bunun için daha çok sosyal bilimlerde kullanılan anket yöntemi kullanılmıştır. $\mathrm{Bu}$ nedenle sorularda nominal (sınıflayıcı) ve aralıklı ölçekler kullanılmıştır. Aynı zamanda açık uçlu sorularda bulunmaktadır. Sınıflayıcı ölçek işletmelerin yapısı hakkındaki bilgileri toplamak için, aralıklı ölçek ise katılımcıların fikirlerinin ne yönde olduğunu belirlemek amacı ile kullanılmıştır. Aralıklı ölçeğe örnek olarak anket çalışmalarında sık kullanılan likert tipi ölçekler gösterilmektedir (Gegez 2007: 195). Bu doğrultuda araştırmanın amacı, önemi, problem cümlesi açılanmakta ve araştırmanın uygulama alanı hakkında bilgi verilmektedir. Daha sonra araştırmanın bulgularını test etmek için takip edilen yol ve yöntemler açıklanmakta ve araştırma sonuçları tarıışılmaktadır.

\subsection{Araştırmanın Önemi}

Dünya'da ve ülkemizde KOBİler, sahip oldukları üretim hacmi, istihdama olan etkileri ve yarattıkları katma değer açısından ekonomik yap1 içinde son derece önemli bir paya sahiptirler. Küresel ve ulusal ölçekli ekonomik krizlerden çok etkilenmektedirler. $\mathrm{Bu}$ krizler ekonominin tüm alanlarında etkisini göstermektedir. Bundan dolayı bu etkinin işletmeler üzerindeki etkilerini tespit etmek ve işletmelerin bu 
konudaki yeteneklerini ve algılarını ortaya koymak gerekmektedir. Ekonomik krizlerin işletmeler üzerindeki etkileri konusu bilimsel olarak araştırılması ve analiz edilmesi gereken bir olgu olarak önem arz etmektedir. Türkiye, küresel ve ulusal düzeydeki ekonomik krizleri yaşayan ve olumsuz etkileri ile mücadele etmek zorunda kalan bir ülkedir. Ülkemizde de Van ili bu krizlerin etkilerini en çok hisseden ve yaşayan şehirlerarasında görülmektedir. Araştırma konusu yapılan Van'daki hizmet sektöründe faaliyet gösteren işletmeler üzerinde ekonomik krizlerin etkileri konusunda bilimsel araştırmaların yetersizliği ve bu zamana kadar bilimsel yöntemler ile ele alınıp değerlendirilmesi önemli ölçüde ihmal edilmiştir. Aynı zamanda KOBI'lerde ekonomik krizlerin nedenleri ve sorunların aşılması amacıyla bu konuda bundan sonra yapılacak çalışmalara öncülük yapacağı gibi, sektörel kullanıcılara ve karar alıcılara yol göstermeye yardımcı olması açısından önem arz etmektedir.

\subsection{Araștırmanın Amaçları}

Araştırma, Ekonomik krizler ve 2000 Y1lı Sonrası Yaşanan Ekonomik Krizlerin Hizmet Sektöründe Van'da Faaliyet Gösteren KOBİ'ler Üzerindeki Etkileri konu almaktadır. Bu amaçla Van'da hizmet sektöründe faaliyette bulunan firmaların durum tespiti yapılarak, çeşitli özellikleri incelenmeye çalışılmıştır. Ayrıca, ekonomik krizlerin firmalar üzerinde etkili olup olmadığı farklı yönlerden belirlenmeye çalışılmıştır.

Araştırmanın amacı; ekonomik krizlerin işletmeler üzerindeki etkilerini ortaya koymak, işletmelerin ekonomik krizlere uyumlarının olumlu etkilerini ve rekabet avantaji elde edip etmedikleri konusunda yöneticilerin algılarını ölçmek ve bu algıların anket kapsamında ele alınan bağımsız değişkenlere göre farklılık gösterip, göstermediğini belirlemektir. Araştırmanın bu genel amacı yanında işletmelerin ekonomik krizler sonucunda elde ettikleri avantajları ve dezavantajları ortaya koymak ve bu alanda bundan sonra yapılacak çalışmalara zemin hazırlamak gibi bazı özel amaçları da vardır.

\subsection{Veri Toplama Aracının Hazırlanması, Geliştirilmesi ve Güvenirlik Analizi}

Araştırma için veri toplamada veri toplama aracı olarak anket tekniği kullanılmıştır. Araştırmanın literatür kısmıyla ilgili alan taraması yapılmıştır. Bu kapsamda, araştırmada faydalanmak üzere, kitap ve makalelere ulaşmak için akademik amaçlı elektronik veri tabanları, yerli ve yabanc1 literatür, üniversite kütüphanelerinden faydalanılmıştır. 
Araştırma ile ilgili olabilecek çalışmaların taranmasında, yurt içinde yapılmış çalışmalar için Yüksek Öğretim Kurulu (YÖK) Dokümantasyon Merkezi, üniversitelerin elektronik veri tabanları, KOSGEB, TOBB, üniversitelerin web sayfaları ve yurt dışındaki çalışmalar için ise yurt dışındaki üniversitelerin elektronik tez veri tabanları ve "Pro Quest Dissertations and Theses" veri tabanından faydalanılmıştır. Literatür taramas1 sürecinde araştırma konusu için ölçek oluşturmada yararlı olabilecek bilgiler ve soru örnekleri biriktirilmiştir.

Tablo 1 : Ölçeklerin Güvenilirlik Katsayıları

\begin{tabular}{|l|c|c|c|}
\hline Ölçek & $\begin{array}{c}\text { Ölçüm } \\
\text { Aralığı }\end{array}$ & $\begin{array}{c}\text { Madde } \\
\text { Sayısı }\end{array}$ & $\begin{array}{c}\text { Cronbach } \\
\text { Alpha } \\
\text { Katsayısı }\end{array}$ \\
\hline $\begin{array}{l}\text { Yaşanan ekonomik krizler ve } \\
\text { etki düzeyleri }\end{array}$ & $\begin{array}{c}5 \text { 'li ölçek } \\
(1-5 \text { arası })\end{array}$ & 4 & 0,963 \\
\hline $\begin{array}{l}\text { Ekonomik krizlerin işletme } \\
\text { faaliyetlerini etkileme düzeyi }\end{array}$ & $\begin{array}{c}5 \text { 'li ölçek } \\
(1-5 \text { arası })\end{array}$ & 7 & 0,973 \\
\hline
\end{tabular}

Ölçek boyutlarının güvenirliliği incelendiğinde tüm boyutlara ilişkin Cronbach's alpha katsayısının 0,70-1,00 arasında olduğu tespit edilmiştir. $\mathrm{Bu}$ değerler, söz konusu ölçme aracının oldukça güvenilir olduğunu göstermektedir. VOS-D kapsamındaki ölçeklerin güvenirliği bu çalışmada yeniden test edilmiş, araştırma anketinde kullanılan tüm ölçeklerin (cronbach's alpha katsayısı) güvenirlikleri yeterli bulunmuştur. Araştırma sonucu elde edilen veriler sistematik bir şekilde değerlendirilmiş ve analiz edilmiştir.

\section{Araştırmaya İlişkin Bulgular ve Değerlendirmeler}

Araştırmaya katılan kişilere ve işletmelere ait istatistiki veriler analiz edilip aşağıdaki tabloda verilmiştir.

Tablo 2: Görüşme Yapılan Kişi Bilgilerine ve İşletme Bilgilerine İlişkin İstatistikler

\begin{tabular}{|l|c|c|l|c|c|}
\hline Kişi Bilgileri & f & $\mathbf{\%}$ & İşletme Bilgileri & f & $\%$ \\
\hline Cinsiyet & & & Faaliyet Süreleri & & \\
\hline Erkek & 48 & 85,7 & $0-5$ Y1l & 14 & 25 \\
\hline Kadın & 8 & 14,3 & $6-10$ Y1l & 16 & 28,6 \\
\hline Yaş & & & $11-15$ Y1l & 15 & 26,8 \\
\hline $20-30$ y1l & 12 & 21,4 & 15 Y1ldan daha fazla & 11 & 19,6 \\
\hline $31-40$ yıl & 22 & 39,3 & Yasal Statüsü & & \\
\hline $41-50$ y1l & 15 & 26,8 & Şahis İsletmesi & 27 & 48,2 \\
\hline 51 yıl ve üzeri & 7 & 12,5 & Limited Şirket & 23 & 41,1 \\
\hline Öğrenim Durumu & & & Anonim Şirket & 6 & 10,7 \\
\hline
\end{tabular}




\begin{tabular}{|c|c|c|c|c|c|}
\hline İlkokul/Ortaokul & 10 & 17,9 & $\begin{array}{lll}\text { İstihdam } & \text { Edilen } & \text { Kişi } \\
\text { Sayısı }\end{array}$ & & \\
\hline Lise & 19 & 33,9 & $1-10$ & 30 & 53,6 \\
\hline Yüksekokul & 10 & 17,9 & $11-50$ & 15 & 26,8 \\
\hline Fakülte & 13 & 23,2 & $51-250$ & 8 & 14,3 \\
\hline Yüksek Lisans + & 4 & 7,1 & 250 den fazla & 3 & 5,4 \\
\hline İşletmedeki pozisyonu & & & Pazar Türü & & \\
\hline İşletme Sahibi/Ortağ1 & 38 & 67,9 & Sadece ulusal pazar & 39 & 69,6 \\
\hline Üst Kademe Yönetici & 11 & 19,6 & Her ikisi de & 10 & 17,9 \\
\hline Orta Kademe Yönetici & 7 & 12,5 & Diğer (lütfen yazınız) & 7 & 12,5 \\
\hline Görev Süresi & & & Son Mali Yıldaki Cirosu & & \\
\hline 1 y1ldan az & 1 & 1,8 & $0,00 \mathrm{TL}-1$ milyon TL & 38 & 67,8 \\
\hline $1-5$ y1l & 14 & 38,5 & $\begin{array}{l}1 \text { milyon bin } \mathrm{TL}-8 \text { milyon } \\
\mathrm{TL}\end{array}$ & 9 & 16,1 \\
\hline $6-10$ y1l & 20 & 35,7 & $\begin{array}{l}8 \text { milyon TL - } 40 \text { milyon } \\
\text { TL }\end{array}$ & 9 & 16,1 \\
\hline 11 ve üzeri & 14 & 25 & Faaliyet Yeri & & \\
\hline $\begin{array}{l}\text { Dâhil Olduğu Hizmet } \\
\text { Kolu }\end{array}$ & & & OSB & 3 & 5,4 \\
\hline Turizm-seyahat & 8 & 14,5 & KSS & 1 & 1,8 \\
\hline İnşaat & 10 & 17,5 & Diğer & 52 & 92,9 \\
\hline Sigorta-bankacilık & 2 & 3,5 & İşletmeyi Kim Yönetiyor & & \\
\hline Ulaşım & 3 & 5,5 & Aile üyeleri & 34 & 60,7 \\
\hline İletişim & 2 & 3,5 & Ortaklar & 6 & 10,7 \\
\hline Eğitim & 6 & 10,5 & Uzman yöneticiler & 10 & 17,9 \\
\hline Sağlik & 3 & 5,5 & Diğer & 6 & 10,7 \\
\hline Yiyecek-içecek & 7 & 12,5 & & & \\
\hline Market-AVM & 3 & 5,5 & & & \\
\hline Diğer & 12 & 21,5 & & & \\
\hline TOPLAM & 56 & 100 & TOPLAM & 56 & 100 \\
\hline
\end{tabular}

Araştırmanın demografik değişkenlerine ilişkin tanımlayıcı istatistiksel ölçülerden yüzde(\%) ve frekans dağılımlarına göre dağıtımlarına Tablo2 'de yer verilmektedir.

Araştırmaya katılan yöneticilerin 48'i erkek eleman, 8'i ise bayan eleman olmak üzere toplam 56 kişiden oluşmaktadır. Buna göre katılımcıların \%85,7'i erkek,\%14'3'ü bayandır. Katılımcıların \% 21,4' ü 20-30 genç yaş grubu olarak, ağırlıklı yaş grubunu; \%39,3 ile 31-40 orta yaş grubu oluştururken, 41-50 yaş grubu \%26,8'lik oranla önemli bir yaş grubu olarak dikkati çekmektedir. Dikkat çeken diğer bir konu da 51 ve üzeri yaş grubunda en az yönetici olmasıdır. Bu durumun seçilen örneklemdeki KOBİ'lerin genç yoğunluklu olmasından kaynaklanıyor olabildiği düşünülmektedir.

Araştırmaya katılan yöneticilerin \%17,9'u ilkokul-ortaokul, \% 33'u lise, \% 17,9'u yüksekokul, \%23,2'i fakülte mezunu olup, \%4'ü ise, yüksek lisans+ eğitimi almışlardır. İşletme yöneticilerinin eğitim durumuna 
bakıldığında önemli bir kısmı $(\% 48,2)$ yükseköğretim mezunu (Yüksekokul, Fakülte, Yüksek lisans + ) olan yöneticilerden oluştuğu görülmektedir. Yükseköğretim mezunu yöneticilerinin oranın bu kadar yüksek olması, KOBI'lerin ekonomik krizleri algılama ve etkilerini azaltma yeteneklerini arttırmaktadır.

Yöneticilerin görevleri ile ilgili dağılım Tablo 2'de gösterilmektedir. Araştırmaya katılan yöneticilerin sayısı 38'i işletme sahibi/ortağı, 11'i üst kademe yönetici ve 7'i orta kademe yönetici olmak üzere toplam 56 kişidir. İşletmelerin aile işletmeleri olmalarından dolayı yöneticilerin önemli bir kısmı işletme sahibi/ortağı ve üst kademe yönetici olarak görev yapmaktadırlar. KOBİ'lerin, ekonomik krizlerle mücadele yetenekleri ve başarıları yöneticilerin bu konudaki tutum ve başarılarına bağlıdır. Ekonomik krizlerin önceden algılanmaları, çalışanlar tarafından mücadele kabiliyeti kazandırılması, çalışanlar üzerindeki olumsuz etkilerini ortadan kaldırmak ve işletme üzerindeki olumsuz etkilerini azaltmak yönetimin sorumluluğundadır.

Tablo 2'de firmanın faaliyette bulunduğu pazarlar ile ilgili istatistiki bilgiler verilmektedir. Firmaların büyük bir kısmı KOBİ niteliğinde ve hizmet sektöründe faaliyet gösteren firmalardır.(Tablo-18'de görüldüğ̈̈ gibi) Van'daki hizmet sektöründeki işletmeler bu özelliklerine rağmen, hem ulusal hem de uluslararası pazarlara çok az firma dâhil olabilmektedirler. Araştırmaya katılan firmaların 54'ü (\%16,1'i) Hem ulusal hem de yurt dişı pazara yönelik faaliyet yapmaktadır. Sadece yurtdışı pazara yönelik faaliyet gösteren firmaların olmaması da önemli bir bulgudur. İşletmelerim büyük bir kısmı yalnız ulusal pazara $(\% 69,6)$ yönelik faaliyette bulunduklarını belirtmişlerdir. $\mathrm{Bu}$ da Van'da hizmet sektöründe faaliyet gösteren firmaların ekonomik krizlerle mücadele etmelerini olumsuz etkilemektedir. Çünkü ihracat yapan firmalar gelirlerini döviz cinsinden elde ettikleri için ekonomik krizlere karşı mukavemet yeteneği daha fazla olur. Bundan dolayı Van'daki hizmet işletmeleri ihracatın ekonomik krizle mücadelede ve etkilerini azaltmadaki olumlu etkilerinden yeterince faydalanamamaktadırlar.

Tablo 2'de firmaların yasal statüleri görülmektedir. İşletmelerin büyük bir kısmının şahıs işletmeleri ve ortaklık düzeyinde kurulan ve faaliyette bulunan işletmelerin olduğunu tablo değerlerine bakılarak söylenebilir. Buna göre, işletmelerin yaklaşı1k yarısı( \%48,2'si) şahıs şirketi niteliğindedir. İşletmelerin $\% 41,1$ 'i şahıs şirketi niteliğindedir. İşletmelerin \%10,7'i anonim şirket niteliğindedir. Buradan işletmelerin büyük çoğunluğunun limited şirket ve şahıs şirketlerinden oluştuğu söylenebilir. İşletmelerin çoğunun şahıs işletmeleri olmaları ekonomik krizler karşısında olumsuz etkilenmelerine yol açmaktadır. Sermaye 
işletmelerinin ekonomik krizlere karşı dayanma kabiliyetleri daha fazladır.

Tablo 3: Krizin İşletmeler Üzerindeki Etkileri, İşletmelerin Krize Bakışı ve Krize Karşı Alınacak Önlemler

\begin{tabular}{|c|c|c|c|c|c|c|c|c|c|}
\hline & \multicolumn{2}{|c|}{ Evet } & \multicolumn{2}{|c|}{ Hayır } & & \multicolumn{2}{|c|}{ Evet } & \multicolumn{2}{|c|}{ Hayır } \\
\hline & $\mathbf{f}$ & $\%$ & $\mathbf{f}$ & $\%$ & & $\mathbf{f}$ & $\%$ & $\mathbf{f}$ & $\%$ \\
\hline \multicolumn{5}{|c|}{ İşletmelerin Öncelikli hedefleri } & \multicolumn{5}{|c|}{ Ekonomik krizlerden etkilenme nedenleri } \\
\hline \begin{tabular}{ll|} 
İşletmenin & yaşamını \\
sürdürmek & \\
\end{tabular} & 37 & 66,1 & 19 & 33,9 & Genel ekonomik faktörler & 45 & 80,4 & 11 & 19 , \\
\hline \begin{tabular}{ll|} 
İşletmenin \\
artırmak
\end{tabular} & 29 & 51,8 & 27 & 48,2 & Teknolojik faktörler & 6 & 10,7 & 50 & 89 \\
\hline $\begin{array}{l}\text { Yatırımları } \\
\text { çeşitlendirmek }\end{array}$ & 9 & 16,1 & 47 & 83,9 & $\begin{array}{l}\text { İşletmenin } \\
\text { sorunları }\end{array}$ & 6 & 10,7 & 50 & \\
\hline Müşteri tatmini & 29 & 51,8 & 27 & 48,2 & Hukuksal so & 7 & 12,5 & 49 & 87,5 \\
\hline İhracat yapmak & - & - & 56 & 100 & Doğal afetler & 18 & 32,1 & 38 & 67,9 \\
\hline $\begin{array}{l}\text { Üretimde } \\
\text { sağlamak }\end{array}$ & 2 & 3,6 & 54 & 96,4 & \begin{tabular}{|lr} 
Rakip & işletmeler \\
rekabetten & ve \\
sorunlar & \\
\end{tabular} & 12 & 21,4 & 44 & \\
\hline Marka imajı oluşturmak & 12 & 21,4 & 44 & 78,6 & k sağlama sorunu & 22 & 39,3 & 34 & 60 , \\
\hline $\begin{array}{l}\text { Gelişme ve büyümeyi } \\
\text { sağlamak }\end{array}$ & 17 & 30,4 & 39 & 69,6 & Diğer(belirtiniz) & 1 & 1,8 & 55 & \\
\hline \multicolumn{5}{|l|}{ Krizin temel nedenleri } & \multicolumn{5}{|l|}{ Krizlerin en olumsuz etkisi } \\
\hline Teknolojik yetersizlikler & 5 & 8,9 & 51 & 91,1 & Satışların düşmesi & 34 & 60,7 & 22 & 39 , \\
\hline Yasal değişiklikler & 15 & 26,8 & 41 & 73,2 & $\begin{array}{l}\text { İşletmede gerilim } \\
\text { çatışmanın }\end{array}$ & 3 & 5,4 & 53 & 94 \\
\hline $\begin{array}{l}\text { İhracat teşviklerinin } \\
\text { yetersizlikleri }\end{array}$ & 1 & 1,8 & 55 & 98,2 & $\begin{array}{|ll|}\text { Finansal } & \text { sorunların } \\
\text { yaşanması } & \\
\end{array}$ & 17 & 30,4 & 39 & 69 \\
\hline \begin{tabular}{l|} 
cilerin \\
zlikleri
\end{tabular} & 11 & 19,6 & 45 & 80,4 & Firma imajının yaşanması & 3 & 5,4 & 53 & 94 \\
\hline $\begin{array}{l}\text { Bankadan alınan kredi } \\
\text { miktarlarını yüksekliği }\end{array}$ & 17 & 30,4 & 39 & 69,6 & Karın azalması & 35 & 62,5 & 21 & 37,5 \\
\hline Öz kaynak yetersizliği & 23 & 41,1 & 33 & 58,9 & \multicolumn{5}{|c|}{ Kriz işletme için neyi ifade ediyor } \\
\hline Planlama yetersizliği & 10 & 17,9 & 46 & 82,1 & $\begin{array}{|ll|}\begin{array}{l}\text { Sikıntılı günlerin } \\
\text { olduğu }\end{array} & \\
\end{array}$ & 27 & 48,2 & 29 & 51, \\
\hline $\begin{array}{l}\text { İşletmenin çevresine } \\
\text { uyum sağlayamaması }\end{array}$ & 5 & 8,9 & 51 & 91,1 & Temkinli olmak gerektiğini & 32 & 57,1 & 24 & 42,9 \\
\hline $\begin{array}{l}\text { Harcamaların } \\
\text { tüketimin k1sılması }\end{array}$ & 6 & 10,7 & 50 & 89,3 & $\begin{array}{l}\text { İşletmenin nakit sıkıntısına } \\
\text { düşebileceği }\end{array}$ & 26 & 46,4 & 30 & 53,6 \\
\hline \multirow[t]{2}{*}{$\begin{array}{l}\text { Nakit } \\
\text { zorunluluğu }\end{array}$} & 10 & 17,9 & 46 & 82,1 & \begin{tabular}{|l} 
İşletmenin ticari \\
faaliyetlerinin sona ereceği
\end{tabular} & 8 & 14,3 & 48 & 85,7 \\
\hline & & & & & $\begin{array}{l}\text { Yeni firsatların ortaya } \\
\text { çıkacağ1 }\end{array}$ & 9 & 16,1 & 47 & 83,9 \\
\hline
\end{tabular}

İşletmenin öncelik hedeflerine ilişkin yöneticilere 8 hedef sorulmuştur. İşletmelerin öncelikli hedeflerinin işletmenin yaşamını sürdürmek olduğu verilen cevaplardan anlaşılmıştır. Buna göre işletmelerin \%66,1'i işletmenin yaşamını sürdürmesini belirtirken, $\% 51,8$ 'i de işletmenin karlılı̆̆ını arıttırmanın öncelikli bir hedef olduğunu ifade etmişlerdir. 
İşletmelerin kriz dönemlerinde en önemli hedefi olan yaşamlarını sürdürme hedefiyle örtüşmektedir.

Tablo 4: İşletmeniz aşağıdaki krizlerden hangisini yaşadı ve nasıl etkilendi?

\begin{tabular}{|c|c|c|c|c|c|c|c|c|c|c|c|c|}
\hline \multirow{2}{*}{\begin{tabular}{|l|} 
Yaşanan \\
ekonomik \\
krizler ve etki \\
düzeyi \\
\end{tabular}} & \multicolumn{2}{|c|}{$\begin{array}{c}\text { Çok } \\
\text { etkilendi }\end{array}$} & \multicolumn{2}{|c|}{$\begin{array}{c}\mathbf{A z} \\
\text { etkilendi }\end{array}$} & \multicolumn{2}{|c|}{ Etkilenmedi } & \multicolumn{2}{|c|}{$\begin{array}{c}\text { Orta } \\
\text { düzeyde } \\
\text { etkiledi }\end{array}$} & \multicolumn{2}{|c|}{$\begin{array}{c}\text { Hiç } \\
\text { etkilemedi }\end{array}$} & \multicolumn{2}{|c|}{$\begin{array}{c}\text { Krizi } \\
\text { yaşamadı }\end{array}$} \\
\hline & $\mathrm{f}$ & $\%$ & $\mathrm{f}$ & $\%$ & $\mathrm{f}$ & $\%$ & $\mathrm{f}$ & $\%$ & $\mathrm{f}$ & $\%$ & $\mathrm{f}$ & $\%$ \\
\hline $\begin{array}{l}2000 \text { y1lı öncesi } \\
\text { kriz }\end{array}$ & 3 & 5,4 & 6 & 10,7 & 6 & 10,7 & 5 & 8,9 & 4 & 7,1 & 33 & 58,9 \\
\hline $\begin{array}{l}2000 \text { y1lı kasım- } \\
\text { aralık krizi }\end{array}$ & 7 & 12,5 & 6 & 10,7 & 6 & 10,7 & 5 & 8,9 & 3 & 5,4 & 29 & 51,8 \\
\hline $\begin{array}{|lrl|}24 & \text { Ocak } 2001 \\
\text { krizleri } & \\
\end{array}$ & 8 & 14,3 & 6 & 10,7 & 6 & 10,7 & 6 & 10,7 & 3 & 5,4 & 27 & 48,2 \\
\hline 2008 y1l1 krizi & 2 & 3,6 & 12 & 21,4 & 25 & 44,6 & 12 & 21,4 & 4 & 7,1 & 1 & 1,8 \\
\hline
\end{tabular}

Tablo 4'de işletmelerin 2000 y1lı öncesinde gerçekleşen krizden \% 58,9 oranında krizi yaşamadığ 1 bunun sebebi işletmelerin 10 yıldan fazla uzun ömürlü olmamasından kaynaklanmaktadır. Ancak 2000 yılı kasım-Aralık ve 24 Ocak 2001 yılı krizini yaşayan işletmelerinde çok etkilendiği anlaşılmaktadır. 2008 yılında yaşanan ekonomik krizden ise işletmelerin \% 3,6 oranında çok etkilendiğini görülmektedir. İşletmelerin büyük bir çoğunluğu etkilerini az miktarda hissetmiştir.

Tablo 5: Ekonomik krizin işletme faaliyetlerinizi nasıl etkiledi?

\begin{tabular}{|l|c|c|c|c|c|c|c|c|c|c|}
\hline $\begin{array}{l}\text { Etki Düzeyleri } \\
\text { Krizin Etkisi }\end{array}$ & \multicolumn{2}{|c|}{$\begin{array}{c}\text { Cok } \\
\text { Etkiledi }\end{array}$} & \multicolumn{2}{|c|}{$\begin{array}{c}\text { Az } \\
\text { Etkiledi }\end{array}$} & \multicolumn{2}{c|}{$\begin{array}{c}\text { Orta } \\
\text { düzeyde } \\
\text { Etkiledi }\end{array}$} & \multicolumn{2}{|c|}{ Etkilemedi } & \multicolumn{2}{|c|}{$\begin{array}{c}\text { Hiç } \\
\text { Etkilemedi }\end{array}$} \\
\hline & f & $\%$ & f & $\%$ & f & $\%$ & f & $\%$ & f & $\%$ \\
\hline $\begin{array}{l}\text { Yönetim } \\
\text { faaliyetleri }\end{array}$ & 9 & 16,1 & 15 & 26,8 & 22 & 39,3 & 9 & 16,1 & 1 & 1,8 \\
\hline $\begin{array}{l}\text { Pazarlama } \\
\text { faaliyetleri }\end{array}$ & 8 & 14,3 & 17 & 30,4 & 22 & 39,3 & 9 & 16,1 & 0 & 0 \\
\hline $\begin{array}{l}\text { Üretim } \\
\text { faaliyetleri }\end{array}$ & 8 & 14,3 & 14 & 25,0 & 23 & 41,1 & 9 & 16,1 & 2 & 3,6 \\
\hline Satış faaliyetleri & 9 & 16,1 & 14 & 25,0 & 24 & 42,9 & 6 & 10,7 & 3 & 5,4 \\
\hline $\begin{array}{l}\text { Tanıtım } \\
\text { faaliyetleri }\end{array}$ & 8 & 14,3 & 16 & 28,6 & 23 & 41,1 & 8 & 14,3 & 1 & 1,8 \\
\hline $\begin{array}{l}\text { Finansman } \\
\text { faaliyetleri }\end{array}$ & 9 & 16,1 & 15 & 26,8 & 24 & 42,9 & 7 & 12,5 & 1 & 1,6 \\
\hline $\begin{array}{l}\text { İnsan } \\
\text { kaynakları }\end{array}$ & 9 & 16,1 & 16 & 28,6 & 22 & 39,3 & 7 & 12,5 & 2 & 3,6 \\
\hline
\end{tabular}

Tablo 5'de işletmelere krizin faaliyetlerini nasıl etkiledi sorusu sorulduğunda, işletmelerin çoğunluğu orta düzeyde etkilediğini ifade etmişlerdir. Bunlardan \% 39,3 düzeyinde yönetim faaliyetleri, \% 39,3 
oranında pazarlama faaliyetleri, \% 41,1 oranında üretim faaliyetleri, \% 42,9 oranında satış faaliyetleri, \% 41,1 oranında tanıtım faaliyetleri, \% 42,9 oranında finansman faaliyetleri ve \% 39,3 oranında insan kaynakları faaliyetlerin etkilendiğini ifade etmişlerdir. Hiç etkilenmeyenlerin sayısı oldukça az görülmektedir. Kriz bir şekilde her işletmenin faaliyetlerini az düzeyde de olsa etkilendiği görülmektedir.

Tablo 6: Kriz anında uygulanan personel politikası nedir?

\begin{tabular}{|l|c|c|}
\hline Personel politikası & f & \% \\
\hline İşten çıarma & 40 & 71,4 \\
\hline Emekliye ayırma & 2 & 3,6 \\
\hline Çalışma sürelerini azaltma & 6 & 10,7 \\
\hline Ücretli izin verme & 2 & 3,6 \\
\hline Değişiklik yapmamak & 6 & 10,7 \\
\hline
\end{tabular}

Tablo 6'da işletmelere kriz anında nasıl bir personel politikası uygulandığını sorulduğunda işlemelerin \% 71,4'ü personeli işten çıkarttığını, \% 10,7 oranında değişiklik yapmadığını ve çalışma sürelerini azatlığını ifade etmiştir.

Tablo 7: Devlet desteği almak için hangi kuruma başvurdunuz?

\begin{tabular}{|l|c|c|c|c|}
\hline \multirow{2}{*}{$\begin{array}{l}\text { Krizi atlatmak için devlet desteklerinden } \\
\text { faydalandınız mı? }\end{array}$} & \multicolumn{2}{|c|}{ Evet } & \multicolumn{2}{c|}{ Hayır } \\
\cline { 2 - 5 } & $\mathbf{f}$ & $\mathbf{\%}$ & $\mathbf{f}$ & $\mathbf{\%}$ \\
\cline { 2 - 5 } & 21 & 36,5 & 35 & 63,5 \\
\hline Devlet desteği almak için hangi kuruma başvurdunuz? & $\mathbf{f}$ & $\mathbf{\%}$ & $\mathbf{f}$ & $\mathbf{\%}$ \\
\hline KOSGEB & 29 & 51,8 & 27 & 48,2 \\
\hline DAKA & 4 & 7,1 & 52 & 92,9 \\
\hline TKDK & 1 & 1,8 & 55 & 98,2 \\
\hline HALKBANKASI & 20 & 35,7 & 36 & 64,3 \\
\hline DIŞ TİCARET MÜŞTEŞARLIĞI & 0 & 0 & 56 & 100 \\
\hline KGF & 1 & 1,8 & 55 & 98,2 \\
\hline DİĞER & 2 & 3,6 & 54 & 96,4 \\
\hline Devlet desteklerinde neden faydalanmadınız? & $\mathbf{f}$ & $\mathbf{\%}$ & $\mathbf{f}$ & $\mathbf{\%}$ \\
\hline Devlet destekleri konusunda bilgimiz yoktu & 9 & 16,1 & 47 & 83,9 \\
\hline Desteğin miktarı ve türleri uygun değildi & 8 & 14,3 & 48 & 85,7 \\
\hline Bürokratik prosedürler çok fazlaydı & 2 & 3,6 & 54 & 96,4 \\
\hline İhtiyacımız yoktu & 5 & 8,9 & 51 & 91,1 \\
\hline
\end{tabular}

Tablo 7'de krizden etkilenen işletmelere krizden etkilenildiğinde hangi kuruma müracaat edildiği sorulduğunda \%51,8 oranında KOSGEB ve \%35,7 oranında Halk Bankasına müracaat edilmiştir. KOSGEB'in ekonomik kriz anında KOBİ'lere destek veren bir kurum olarak algılanmaktadır. Diğer destek veren kamu kurumlarına çık az sayıda 
müracaat yapıldığı gözlenmektedir. KOSGEB'in daha çok Kredi Faiz Desteğine müracaat edilmesi muhtemeldir.

\section{Sonuç}

Ekonomik krizlerin en önemli özelliği yalnızca çıktıkları ülkeleri değil bütün dünya ülkelerini etkilemeleri ve bulaşıcı olabilmeleridir. Özellikle 1980'li yıllara gelindiğinde gelişmekte olan ülkelerde, krizlerin sayısının ve şiddetinin arttığ 1 görülmektedir. Genelde tüm dünya ve özelde Türkiye açısından önemli bir konu olan ekonomik krizlerin olumsuz etkilerini en aza indirebilmek, ekonomik krizleri inceleyerek Türkiye'de 2000 y1lından sonra ortaya çıkan krizlerde hizmet sektöründe faaliyet gösteren KOBİ'lere etkilerini tespit etmek amacıyla yaptığımız bu çalışmada, şu sonuçlara varılmıştır;

Çalışmada genel olarak kriz ile ilgili genel kavramlar açıklandıktan sonra KOBİ'ler üzerindeki etkileri analiz edilmiştir. 1999-2000 yılları arasında finansal serbestleşmenin etkisiyle dayanıklı tüketim kredilerinde sağlanan kolaylıklar, tüketim ve lüks malların ithalatını artırmış ve ihracatın ithalatı karşılama oranı giderek zayıflamıştır. Özelleştirme ile ilgili alınan kararlar uygulanamamış, hatta üst düzey siyasiler hakkında toplumda şaibeler çıkmıştır. Bu olumsuzluklara banka ve finans çevrelerinin para aklama, para hortumlama ve dışarıdan sağlanan fonları yüksek faizle ülke içerisinde kullanıp faiz-kur arbitrajı yaparak para kazanmaları da eklenmiştir. Yine bankaların yurtdışından sağladıkları fonları kurun yükseleceği endişesiyle dövize çevirmeleri Kasım 2000 krizine neden olmuştur.

Araştırmaya katılan KOBI'lerin \%82,2'i krizin işletmeleri olumsuz etkilediğini belirtirken; \%17,8'i k1smen olumsuz etkilediğini belirtmişlerdir. Araştırmaya katılan işletmelerden hiçbiri krizin işletmelerini etkilemediğini belirtmemişlerdir. Elde edilen veriler ve KOBİ'lerin ekonomi için önemi düşünüldüğünde KOBİlerin, krizlere karşı strateji geliştirme gerekliliği ön plana çıkmaktadır.

KOBİ'ler sınırların ekonomik anlamda sembolik hale geldiği günümüzde teknolojiye ayak uydurmalı, rakiplerini iyi tanımalı, yeniliklere açık olmalı ve küreselleşmenin getireceği olası krizleri firsata çevirebilme kabiliyetine sahip olmalıdırlar. Ancak KOBİ'lerin bu kabiliyetlere haiz olması için profesyonel anlamda iyi ve eğitimli yöneticilere sahip olmaları gerekmektedir. Zira araştırmaya katılan KOBI'lerin krizden etkilenme dereceleri yönetici eğitimine bağlı olarak değişim arz etmektedir. Yöneticinin eğitim seviyesi arttıkça krize karşı planlama artmakta ve krizden etkilenme derecesi de o derece azalmaktadır. 


\section{Kaynaklar}

Albert, M. (2004). Katılımcı Ekonomi, İstanbul, Arom Yayıncılık.

Alıç, A. B., Akboğa, B., Aslan, A. ve Kayabaşı, G. (2009). Küresel Krizin KOBİ'lerin İhracatlarına Etkileri ve KOBI'lerde Kriz Yönetimi: Eskişehir İli KOBI'ler Üzerine Bir Araştırma, XII. Uluslararası İktisat Öğrencileri Kongresi / 7-8 Mayıs 2009 / Ege Üniversitesi İIBBF/ İzmir-Türkiye.

Bakır, H. (2018). Neo-Liberalizm, Küresel Kriz ve Emek Piyasasında Yaşanan Dönüşümler: Güney Avrupa Bağlamında Bir Değerlendirme, AIBÜ Sosyal Bilimler Enstitüsü Dergisi, Cilt:18, Y11:18, Say1: 3, s.1-30.

Çağlar, S. Ö. (2010). Küresel Ekonomik Krizler ve Türkiye'deki Reel Sektör Üzerine Etkileri: Otomotiv Sektörü Örneği, Sakarya Üniversitesi Yüksek Lisans Tezi.

Delice, G. (2003). Finansal Krizler: Teorik ve Tarihsel Bir Perspektif, Erciyes Üniversitesi IBF Dergisi, s.57-81.

Demirci, N. (2005). Finansal Krizlerin Anatomisi Modern Kriz Teorileri Işığında Gelişmekte Olan Ülkeler ve Türkiye, Ankara: Sermaye Piyasası Kurulu Yayını.

Durgun, A. (2010). Ekonomik Krizlerin Turizm Sektörüne Etkileri 2008 Küresel Krizinin Antalya Konaklama İşletmelerine Etkilerinin Analizi, Süleyman Demirel Üniversitesi SBE Doktora Tezi, Isparta.

Eğilmez, M. (2008). Küresel Finans Krizi, Piyasa Sisteminin Eleştirisi, İstanbul Ticaret Odası Yayınları.

Ekşi, İ.H. (2007). Finansal Krizlerin KOBİ'ler Üzerindeki Etkileri ve Başarıl1-Başarısız KOBI'lerden Kriz Dönemi Stratejileri, Süleyman Demirel Üniversitesi SBE Doktora Tezi, Isparta.

Emin, Ç. (2001). 2000-2001 Yll1 Ekonomik Krizlerin Sebepleri Ve Sonuçları, Yeni Türkiye: Ekonomik Kriz Özel Sayısı, Cilt:1 Sayı:42.

Emsen, Ö. S. (2003). Ekonomik Krizler ve Türkiye Deneyimi”, Beta Yayınlart.

Fred, B. (1979). The Origins of International Economic Disorders Berkeley: University of California Press.

http://krizyonetimi.com.tr/kriz_nedir.html (E.T. 19 May1s 2018). 
Gegez, A. E. (2007). Pazarlama Araştırmaları, Beta Yayınları İstanbul.

Goodhart, C. A. E. (2008). The Background To The 2007 Financial Crisis, Springer- Verlag Forum, s.331-346

Gürsoy, M. (1989). Dünyada Büyük Ekonomik Krizler ve Türkiye Ekonomisine Etkileri, İstanbul: $M G$ Yayınlart.

Güzel, A., Ünsal B. ve Yüksel İ. (2010). Küresel Mali Krize Karşı Türk Kobi"elerinde Davranış Şekilleri ve Değişiklikleri, TSA / Yıl: 14, Say1: 1.

Hui, T. ve Wei, S.J. (2008). Real Effects of Subprime Mortgage Crisis: Is It a Demond or a Finance Shock?, NBER Working Paper 14205, http://www.nber.org. (E.T. 20.03.2018).

Irvine, R.B. (1987). What's a Crisis, Anyway, Midyear Special, 4.

Kınaytürk, Z., (2006). 1990 Yılından Sonra Yaşanan Ekonomik Krizlerin KOBİ'ler Üzerindeki Etkileri, Yayınlanmamış Y.L Tezi, Süleyman Demirel Üniversitesi, Sosyal Bilimler Enstitüsü.

Kibritçioğlu, A. (2001). Türkiye' de Ekonomik Krizler ve Hükümetler, Yeni Türkiye Ekonomi Dergisi, Özel Say1 41.

Mendoza, E. ve Quadrini, V. (2010). Financial Globalization, Financial Crises and Contagion, NBER Working Paper No. 15432.

Mitroff, I. (1987). Effective Crisis Management, The Academy of Management Executive, 1(3).

Nanto, Dick K. (2009). The Global Financial Crisis: Analysis and Policy Implications, Congressional Research Service.

Öksüzler, O., ve Teyyare, E., (2010). Küresel Ekonomik Kriz Sürecinde Türkiye'de Alınan Önlem Paketlerinin İstihdam Üzerindeki Etkileri, Yönetim ve Ekonomi Araştırmaları Dergisi, Cilt 8, Sayı 14.

Perelman, M. (2008). Kriz Hakkında Nasıl Düşünülmeli, Neoliberalizm ve Kriz, I. Basım, İstanbul, Kalkedon Yayınları.

Roubini, N. ve Mihm, S., (2012). "Kriz Ekonomisi Dünya Ekonomisinin Çöküşü ve Geleceğì", Çev. Tezcan, I., Pegasusu Yayınları.

Stiglitz, J. (2002), Küreselleşme Büyük Hayal Kırıklığı, İstanbul, Plan B Yay.

Tabb, William K. (2008). ABD Kapitalizmin Finansal Krizi, Neoliberalizm ve Kriz", I. Basım, İstanbul, Kalkedon Yayıncllı. 
Tuğlacı, P. (1997). İngilizce-Türkçe Tıp Sözlüğü, İstanbul: ABC Kitabevi.

Turgut, A. (2006). Finansal Krizlerde IMF’nin Rolü Ve Önemi: 1997 Asya Ve 2000- 2001 Türkiye Krizleri, Selçuk Üniversitesi Karaman I.I.B.B.F. Dergisi, Y11: 9, Say1:10, s.1-14.

Vergil, H., ve Teyyare, E., (2014). Teorik Perspektiften Para Krizi Modelleri ve Kurumsal Model Örneği, Finans Politik ve Ekonomik Yorumlar Dergisi, Y11: 51, Say1: 591.

Wolhberg, J. W. , Christian, T. H. (1989). Organizational Behavoir: Cases Exercises Reading And An Extented Simulation, Boston Hougton Mifflin Company.

Yalçın, A. ve Gafuroğlu, Ş. (2008). Ekonomik Krizlerin Küçük ve Orta Ölçekli İşletmeler Üzerindeki Yönetsel ve İşlevsel Etkilerini Belirlemeye Yönelik Ampirik Bir Araştırma, Ç.Ü. Sosyal Bilimler Enstitüsü Dergisi, Cilt 17, Say1 2, s.433-448. 